Article

\title{
Cytinus hypocistis (L.) L. subsp. macranthus Wettst.: Nutritional Characterization
}

\author{
Ana Rita Silva ${ }^{1,2}$, Ângela Fernandes ${ }^{1}$, Pablo A. García ${ }^{2}{ }^{\circledR}$, Lillian Barros ${ }^{1}{ }^{\circledR}$ and \\ Isabel C.F.R. Ferreira $1, *$ (D) \\ 1 Centro de Investigação de Montanha (CIMO), Instituto Politécnico de Bragança, Campus de Santa Apolónia, \\ 5300-253 Bragança, Portugal; silva-ana@ipb.pt (A.R.S.); afeitor@ipb.pt (A.F.); lillian@ipb.pt (L.B.) \\ 2 Departamento de Ciencias Farmacéuticas, Facultad de Farmacia, CIETUS-IBSAL, University of Salamanca, \\ Campus Miguel de Unamuno, 37007 Salamanca, Spain; pabloagg@usal.es \\ * Correspondence: iferreira@ipb.pt; Tel.: +351-273-303219; Fax: +351-273-325405
}

Received: 14 March 2019; Accepted: 16 March 2019; Published: 20 March 2019

check for updates

\begin{abstract}
The habit of eating wild plants in Europe is often associated with times of famine; an example of such is the nectar of Cytinus hypocistis (L.) L., a parasitic plant. To the authors' best knowledge, there are no studies on its nutritional and chemical composition; thus, the whole C. hypocistis (L.) L. subsp. macranthus Wettst. plant $(\mathrm{CH})$ and its nectar $(\mathrm{NCH})$ were nutritionally and chemically characterized. The proximate composition of $\mathrm{CH}$ and $\mathrm{NCH}$ were very similar in terms of energy, ash, and carbohydrate content. Protein and fat were approximately 2-fold higher in NCH, and crude fiber was 4.6-fold higher in $\mathrm{CH}$ compared to NCH. Fructose, glucose, sucrose, and trehalose were the free sugars present in both samples. Oxalic, malic, and citric acids were the identified organic acids in both samples, with citric acid as the most abundant molecule. For both samples, polyunsaturated and saturated fatty acids (PUFA and SFA, respectively) predominate over monounsaturated fatty acids (MUFA) due to the significant contribution of linoleic and palmitic acids, respectively. However, unsaturated fatty acids (UFA) prevail over SFA in CH and NCH. Therefore, $\mathrm{CH}$ proved to be an excellent source of nutritional compounds, which supports its use during past periods of scarcity.
\end{abstract}

Keywords: Cytinus hypocistis (L.) L. subsp. macranthus Wettst.; famine food; holoparasite; nectar; nutritional and chemical characterization; wild edible plant

\section{Introduction}

Wild edible plants have been an integral part of human nutrition since ancient times, and many species now considered as weeds were food substitutes, the most common individual subsistence strategy in times of want and starvation for numerous cultures [1-3]. Indeed, all the early studies on the use of wild food plants in Europe, beginning in the 19th century to approximately the 1960s, captured the history of famine and the use of wild plants as a means of basic survival [2]. Despite agricultural societies' primary dependence on crop plants, the tradition of eating wild plants has not completely disappeared [4-7]. An example of such is the parasitic plant Cytinus hypocistis [7-9]. Approximately $1 \%$ of angiosperms are parasitic [10-12], and one of the most extreme manifestations of this type of parasitism is found within the Cytinaceae family, composed of the Cytinus, Bdallophyton, and Bdallophytum genera $[8,13]$. Cytinus are rootless, stemless, and leafless holoparasites with a vegetative body reduced to an endophytic system that grows exclusively inside its host root, and from which nutrients and water are absorbed [13]. This genus occurs in the Mediterranean region, South Africa, and Madagascar, and the flowers are only visible when they emerge from the host tissue during the reproductive period [8]. In Europe, there are two recognized species of Cytinus_Cytinus hypocistis 
(L.) L. and Cytinus ruber (Fourr.) ex Fritsch—that parasitize roots of Cistus and Halimium spp. and two genera of shrub plants within the Cistaceae family. Cytinus hypocistis (L.) L. is divided into four subspecies, each with a distinct host range: subsp. hypocistis parasitize on various Cistus and Halimium spp., subsp. macranthus parasitize on Halimium spp., subsp. orientalis parasitize on Cistus parviflorus, and subsp. pityusensis parasitize on Cistus clusii [6,14-16].

Three different studies on wild plants traditionally used for human consumption in Portugal and Spain quoted C. hypocistis as famine food; its nectar was sucked as sweets or spread on rye bread during the working day to avoid hunger pains $[6,7,16]$. From the nutritional point of view, flowers can be divided into three major components (pollen, nectar, and petals) and other parts, which can play a role in human nutrition [17]. Nectar is the second most important component; it is usually a sweetish liquid which contains a balanced mixture of sugars (fructose, glucose, and sucrose), amino acids, proteins, inorganic ions, lipids, organic acids, phenolic substances, alkaloids, and terpenoids, among others [18].

According to a semi-quantitative approach that compares the cultural importance of 97 wild edible plant species of the Iberian Peninsula, C. hypocistis occupies position 44 in the ranking [7]. Despite the cultural relevance of this plant, its chemical characterization is largely unknown $[8,19,20]$, and to the author's best knowledge, its nutritional composition is not yet identified. For a comprehensive discussion to help bridge this gap, and since C. hypocistis nectar accounts for $70 \pm 0.5 \%$ of its flower weight, the authors compared the obtained data with published results from other studies on different edible flowers. Therefore, C. hypocistis subsp. macranthus Wettst. was nutritionally characterized based on its protein, fat, ash, fiber, and carbohydrate content, following which we calculated its energetic value. Furthermore, its individual content in sugars, organic acids, and fatty acids was also determined.

\section{Results and Discussion}

According to the literature, water is the main constituent (70 to 95\%) and carbohydrates are the most abundant macronutrient (42.4 to $90.2 \mathrm{~g} / 100 \mathrm{~g}$ dry weight basis- $\mathrm{dw}$ ) in edible flowers [21]. The nutritional profiles of the whole C. hypocistis (L.) L. subsp. macranthus Wettst. plant $(\mathrm{CH})$ and its nectar $(\mathrm{NCH})$ are presented in Table 1 and were within the range for edible flowers reported in the literature [21]. The humidity contents of $\mathrm{CH}$ and $\mathrm{NCH}$ were $78 \%$ and $25 \%$, respectively. Protein (9.4 versus $4.90 \mathrm{~g} / 100 \mathrm{~g} \mathrm{dw}$ ) and fat (1.4 versus $0.67 \mathrm{~g} / 100 \mathrm{~g} \mathrm{dw}$ ) values were approximately 2-fold higher in $\mathrm{NCH}$ in comparison to $\mathrm{CH}$. Unlike ash $(2.87 \mathrm{~g} / 100 \mathrm{~g} \mathrm{dw}$ for $\mathrm{CH}$ and $3.05 \mathrm{~g} / 100 \mathrm{~g} \mathrm{dw}$ for $\mathrm{NCH})$ and carbohydrates $(86.8 \mathrm{~g} / 100 \mathrm{~g} \mathrm{dw}$ for $\mathrm{CH}$ and $85.1 \mathrm{~g} / 100 \mathrm{~g} \mathrm{dw}$ for $\mathrm{NCH})$, where the content in both samples were very similar, crude fiber was 4.6-fold higher in $\mathrm{CH}$ compared to NCH (4.76 versus $1.03 \mathrm{~g} / 100 \mathrm{~g} \mathrm{dw})$. Altogether, these factors contributed to a very similar energetic value for both samples (382.4 kcal/100 $\mathrm{g} \mathrm{dw}$ for $\mathrm{CH}$ and $392.9 \mathrm{kcal} \mathrm{g/100} \mathrm{g} \mathrm{dw}$ for $\mathrm{NCH}$ ).

The soluble sugar composition of the two samples is also shown in Table 1. Two reducing (i.e., fructose and glucose) and two non-reducing (i.e., sucrose and trehalose) sugars were detected in both samples. Fructose is known to be the sweetest of all naturally occurring carbohydrates [22] and was the main sugar present in $\mathrm{CH}$, almost 9-fold higher $(6.3 \mathrm{~g} / 100 \mathrm{~g} \mathrm{dw})$ than in NCH $(0.71 \mathrm{~g} / 100 \mathrm{~g}$ $\mathrm{dw})$. Glucose was also almost 9-fold higher in $\mathrm{CH}(1.92 \mathrm{~g} / 100 \mathrm{~g} \mathrm{dw})$ than in NCH (0.22 g/100 g dw). Although sucrose was the main soluble sugar present in $\mathrm{NCH}$, its concentration was almost 2-fold lower $(0.85 \mathrm{~g} / 100 \mathrm{~g} \mathrm{dw})$ than in $\mathrm{CH}(1.37 \mathrm{~g} / 100 \mathrm{~g} \mathrm{dw})$. Contrary to the other three sugars, trehalose content was similar for both samples, $0.95 \mathrm{~g} / 100 \mathrm{~g} \mathrm{dw}$ in $\mathrm{CH}$ and $0.80 \mathrm{~g} / 100 \mathrm{~g} \mathrm{dw}$ in NCH. The total sugar content was 4-fold higher in the whole plant (10.5 g/100 g dw versus $2.58 \mathrm{~g} / 100 \mathrm{~g} \mathrm{dw})$, mainly due to the contribution of fructose. Nectar is described in the literature as containing a balanced mixture of sugars [17], and NCH was found to have a very similar content of fructose, sucrose, and trehalose, confirming this information. 
Table 1. The nutritional value, soluble sugars, and organic acids composition of Cytinus hypocistis subsp. macranthus Wettst. (L.) L. using the whole plant $(\mathrm{CH})$ and its nectar $(\mathrm{NCH})$. Mean \pm SD.

\begin{tabular}{|c|c|c|c|}
\hline \multirow{2}{*}{ Moisture (\%) } & $\mathrm{CH}$ & $\mathbf{N C H}$ & Student's $t$-Test $p$-Value \\
\hline & $78 \pm 1$ & $25 \pm 1$ & $<0.001$ \\
\hline Nutritional value & \multicolumn{2}{|c|}{$g / 100 \mathrm{~g} \mathrm{dw}$} & \\
\hline Fat & $0.67 \pm 0.03$ & $1.4 \pm 0.1$ & $<0.001$ \\
\hline Proteins & $4.90 \pm 0.07$ & $9.4 \pm 0.3$ & $<0.001$ \\
\hline Ash & $2.87 \pm 0.02$ & $3.05 \pm 0.05$ & 0.005 \\
\hline Fiber & $4.8 \pm 0.1$ & $1.03 \pm 0.05$ & $<0.001$ \\
\hline Carbohydrates & $86.8 \pm 0.2$ & $85.1 \pm 0.4$ & 0.002 \\
\hline Energy contribution (kcal/100 g dw) & $382.4 \pm 0.1$ & $392.9 \pm 0.1$ & $<0.001$ \\
\hline Soluble sugars & \multicolumn{2}{|c|}{$g / 100 \mathrm{~g} \mathrm{dw}$} & \\
\hline Fructose & $6.3 \pm 0.1$ & $0.71 \pm 0.01$ & $<0.001$ \\
\hline Glucose & $1.92 \pm 0.05$ & $0.22 \pm 0.02$ & $<0.001$ \\
\hline Sucrose & $1.37 \pm 0.05$ & $0.85 \pm 0.01$ & $<0.001$ \\
\hline Trehalose & $0.95 \pm 0.02$ & $0.80 \pm 0.04$ & 0.001 \\
\hline Total & $10.5 \pm 0.2$ & $2.58 \pm 0.07$ & $<0.001$ \\
\hline Organic acids & \multicolumn{2}{|c|}{$g / 100 \mathrm{~g} \mathrm{dw}$} & \\
\hline Oxalic acid & $0.030 \pm 0.001$ & tr. & - \\
\hline Malic acid & $0.40 \pm 0.01$ & $0.45 \pm 0.02$ & 0.007 \\
\hline Shikimic acid & tr. & nd. & - \\
\hline Ascorbic acid & nd. & $0.180 \pm 0.002$ & - \\
\hline Citric acid & $0.41 \pm 0.01$ & $1.48 \pm 0.01$ & $<0.001$ \\
\hline Total & $0.85 \pm 0.02$ & $2.11 \pm 0.03$ & $<0.001$ \\
\hline
\end{tabular}

dw-dry weight basis, tr.-traces, and nd.—not detected.

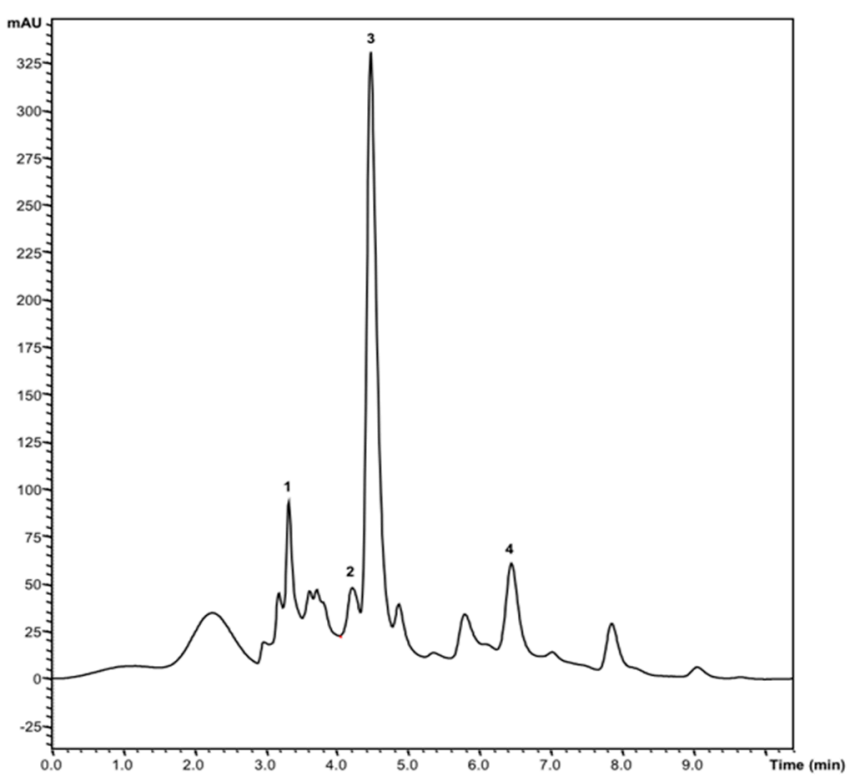

Figure 1. Organic acids chromatogram profile of the $\mathrm{CH}$ sample at $215 \mathrm{~nm}$ : 1-oxalic acid, 2-malic acid, 3-ascorbic acid, and 4-citric acid.

Three different organic acids were identified in both samples $(\mathrm{CH}$ and $\mathrm{NCH})$ : oxalic $(0.030 \mathrm{~g} / 100 \mathrm{~g}$ $\mathrm{dw}$ versus traces), malic $(0.40 \mathrm{~g} / 100 \mathrm{~g}$ dw versus $0.45 \mathrm{~g} / 100 \mathrm{~g} \mathrm{dw})$, and citric acids $(0.41 \mathrm{~g} / 100 \mathrm{~g} \mathrm{dw}$ versus $1.48 \mathrm{~g} / 100 \mathrm{~g} \mathrm{dw})$. Contrarily, ascorbic acid was only detected in $\mathrm{NCH}(0.180 \mathrm{~g} / 100 \mathrm{~g} \mathrm{dw})$ and traces of shikimic acid were detected in $\mathrm{CH}$. As presented in Figure 1, the total organic acids content was 2.48-fold higher in $\mathrm{NCH}(2.11 \mathrm{~g} / 100 \mathrm{~g} \mathrm{dw})$ compared to $\mathrm{CH}(0.85 \mathrm{~g} / 100 \mathrm{~g} \mathrm{dw})$. All detected organic acids are of the utmost importance for human metabolism since they are described as beneficial for a healthy diet [23]. 
Regarding tocopherols content, only traces of $\alpha$-tocopherol isoform were detected in $\mathrm{CH}$.

Results regarding the fatty acids composition of $\mathrm{CH}$ and $\mathrm{NCH}$ are given in Table 2 . The fatty acids profile showed 25 compounds for $\mathrm{CH}$ and 26 for $\mathrm{NCH}$. Polyunsaturated fatty acids (PUFA) were the major group, followed by saturated fatty acids (SFA) and monounsaturated fatty acids (MUFA). Humans lack the enzymes required to produce the two essential fatty acids: $\omega-3$ PUFA- $\alpha$-linolenic and $\omega-6$ PUFA-linoleic. Although the synthesis rate may not be sufficient to meet human requirements, and it is, hence, recommended that good sources of these fatty acids are also included in the diet, humans can elongate dietary $\alpha$-linolenic acid to the long chain $\omega$-3 PUFAs, namely eicosapentaenoic and docosahexaenoic acids [24]. PUFA corresponds to $46.95 \%$ of the fatty acids present in $\mathrm{CH}$ and $49 \%$ in $\mathrm{NCH}$, mainly due to the high content of linoleic acid in both samples $(40.08 \%$ and $39.903 \%$, respectively). Linoleic and $\alpha$-linolenic acids are present in high percentages in some edible flowers $(>50 \%)$, such as Calendula officinalis L. and Trifolium angustifolium L. [25]. $\mathrm{CH}(42.14 \%)$ and $\mathrm{NCH}(43.62 \%)$ stayed just below the $50 \%$ cut-off line. Linoleic and $\alpha$-linolenic acids have important roles in human growth and development, as well as in the prevention and treatment of coronary artery diseases, hypertension, diabetes, arthritis, other inflammatory and autoimmune disorders, and cancer [25-30]. SFA is the second group of fatty acids with similar predominance in $\mathrm{CH}(35.56 \%)$ and $\mathrm{NCH}(35.36 \%)$, largely due to the high content of palmitic acid (24.12 and $24.76 \%$, respectively). Palmitic acid is one of the most common SFA found in edible plants. Although it is associated with increased risk of developing cardiovascular diseases [31], oxidative DNA damage, DNA strand breakage, necrosis, and apoptosis in human cells in vitro [32,33], when consumed with other fatty acids, like PUFAs, SFA are unlikely to have any significant impact on human health [25,32,34]. A recent review highlighted that further research is needed to unveil the true advantages and disadvantages induced by palmitic acid consumption [35]. $\mathrm{CH}$ and $\mathrm{NCH}$ also contain other saturated fatty acids in lower concentrations, such as stearic (CH: $5.19 \%, \mathrm{NCH}: 4.79 \%)$, arachidic (CH: $1.87 \%, \mathrm{NCH}: 1.453 \%)$, and behenic acids $(\mathrm{CH}$ : $1.86 \%, \mathrm{NCH}: 1.57 \%)$. MUFA makes up the smallest contribution to the fatty acids content in $\mathrm{CH}(17.5 \%)$ and $\mathrm{NCH}(15.31 \%)$, mainly due to the presence of oleic acid (CH: $15.4 \%, \mathrm{NCH}: 13.70 \%)$. Both samples presented small percentages of palmitoleic $(\mathrm{CH}: 0.662 \%$, NCH: $0.628 \%)$, elaidic $(\mathrm{CH}: 1.10 \%, \mathrm{NCH}$ : $0.861 \%$ ), and eicosanoic acids ( $\mathrm{CH}: 0.366 \%, \mathrm{NCH}: 0.121 \%$ ). As it has been shown, olive oil induces its hypotensive effects through the action of oleic acid and, according to Fernandes et al. [25], one of the highest percentages of this fatty acid present in edible flowers was found in Gundelia tournefortii L. buds $(28.5 \%)[25,36]$. For both samples (Table 2), PUFA and SFA predominate over MUFA due to the significant contribution of linoleic and palmitic acids, respectively. However, unsaturated fatty acids (UFA) prevail over SFA (64.44\% versus $35.56 \%$ in $\mathrm{CH}$ and $6.9 \%$ versus $35.36 \%$ in $\mathrm{NCH}$ ). According to the literature, with the exception observed in calendula flowers $(23.3 \%)$, unsaturated fatty acids predominate over saturated ones for edible flowers, usually being higher than 53\% [25]. According to Fernandes et al. [25], in general all edible flowers studied until now showed high ratios (above 0.45) of PUFA/SFA, which are known to help reduce the risk of cardiovascular diseases [34], and the Cytinus hypocistis (L.) L. plant is no exception. The PUFA/SFA ratios for $\mathrm{CH}$ and $\mathrm{NCH}$ were 1.320 and 1.37 , respectively.

Table 2. Fatty acids composition of Cytinus hypocistis subsp. macranthus Wettst. (L.) L. using CH and $\mathrm{NCH}($ Mean $\pm \mathrm{SD})$.

\begin{tabular}{cccc}
\hline Fatty Acids (Relative Percentage, \%) & CH & NCH & Student's $\boldsymbol{t}$-Test $\boldsymbol{p}$-Value \\
\hline Caproic acid (C6:0) & nd. & $0.100 \pm 0.001$ & - \\
Caprilic acid (C8:0) & $0.030 \pm 0.003$ & $0.033 \pm 0.001$ & 0.178 \\
Capric acid (C10:0) & $0.037 \pm 0.003$ & $0.036 \pm 0.001$ & 0.011 \\
Undecylic acid (C11:0) & $0.016 \pm 0.001$ & $0.042 \pm 0.001$ & $<0.001$ \\
Lauric acid (C12:0) & $0.315 \pm 0.002$ & $0.268 \pm 0.001$ & $<0.001$ \\
Myristic acid (C14:0) & $0.425 \pm 0.001$ & $0.384 \pm 0.001$ & $<0.001$ \\
Pentadecylic acid (C15:0) & $0.15 \pm 0.01$ & $0.13 \pm 0.01$ & 0.001 \\
Palmitic acid (C16:0) & $24.12 \pm 0.07$ & $24.76 \pm 0.02$ & $<0.001$ \\
\hline
\end{tabular}


Table 2. Cont.

\begin{tabular}{cccc}
\hline Fatty Acids (Relative Percentage, \%) & CH & NCH & Student's $t$-Test $p$-Value \\
\hline Palmitoleic acid (C16:1) & $0.662 \pm 0.001$ & $0.628 \pm 0.001$ & $<0.001$ \\
Margaric acid (C17:0) & $0.311 \pm 0.004$ & $0.305 \pm 0.001$ & $<0.001$ \\
Stearic acid (C18:0) & $5.19 \pm 0.04$ & $4.79 \pm 0.01$ & $<0.001$ \\
Elaidic acid (C18:1n9t) & $1.10 \pm 0.02$ & $0.86 \pm 0.01$ & $<0.001$ \\
Oleic acid (C18:1n9c) & $15.4 \pm 0.1$ & $13.7 \pm 0.1$ & $<0.001$ \\
Linolelaidic acid (C18:2n6t) & $2.16 \pm 0.01$ & $1.88 \pm 0.01$ & 0.001 \\
Linoleic acid (C18:2n6c) & $40.08 \pm 0.02$ & $39.90 \pm 0.03$ & $<0.001$ \\
$\gamma$-Linolenic acid (C18:3n6) & $1.088 \pm 0.001$ & $0.940 \pm 0.005$ & $<0.001$ \\
$\alpha$-Linolenic acid (C18:3n3) & $2.07 \pm 0.06$ & $3.72 \pm 0.02$ & $<0.001$ \\
Arachidic acid (C20:0) & $1.87 \pm 0.01$ & $1.45 \pm 0.01$ & $<0.001$ \\
Eicosanoic acid (C20:1) & $0.366 \pm 0.004$ & $0.121 \pm 0.004$ & $<0.001$ \\
cis-11,14-Eicosadienoic acid (C20:2) & $1.471 \pm 0.005$ & $1.273 \pm 0.001$ & 0.001 \\
Heneicosanoic acid (C21:0) & $0.22 \pm 0.01$ & $0.25 \pm 0.01$ & 0.001 \\
Arachidonic acid (C20:4n6) & $0.028 \pm 0.001$ & $0.034 \pm 0.002$ & $<0.001$ \\
Behenic acid (C22:0) & $1.86 \pm 0.06$ & $1.57 \pm 0.01$ & 0.001 \\
cis-13,16-Docosadienoic acid (C22:2) & $0.058 \pm 0.001$ & $0.037 \pm 0.001$ & $<0.001$ \\
Tricosanoic acid (C23:0) & $0.182 \pm 0.003$ & $0.191 \pm 0.004$ & 0.003 \\
Lignoceric acid (C24:0) & $0.83 \pm 0.03$ & $2.60 \pm 0.02$ & $<0.001$ \\
SFA & $35.56 \pm 0.09$ & $35.36 \pm 0.02$ & 0.006 \\
MUFA & $17.5 \pm 0.1$ & $15.3 \pm 0.1$ & $<0.001$ \\
PUFA & $46.95 \pm 0.04$ & $49 \pm 1$ & 0.022 \\
UFA & $64.4 \pm 0.1$ & $63.8 \pm 0.8$ & 0.282 \\
PUFA/SFA & $1.32 \pm 0.01$ & $1.37 \pm 0.02$ & 0.015 \\
\hline
\end{tabular}

dw—dry weight basis, nd.—not detected, SFA—saturated fatty acids, MUFA—monounsaturated fatty acids, PUFA - polyunsaturated fatty acids, and UFA — unsaturated fatty acids.

\section{Materials and Methods}

\subsection{Reagents and Standards}

Acetonitrile (99.9\%), $n$-hexane (95\%), and ethyl acetate (99.8\%) were of HPLC grade from Fisher Scientific (Lisbon, Portugal). All the individual compounds were of HPLC or GC grade, the fatty acids methyl ester (FAME) reference standard mixture 37 (standard 47,885-U) was purchased from Sigma (St. Louis, MO, USA), as well as other individual fatty acid isomers, L-ascorbic acid, tocopherols ( $\alpha-$, $\beta-, \gamma-$, and $\delta$-isoforms), and sugars (D(-)-fructose, $\mathrm{D}(+)$-glucose anhydrous, $\mathrm{D}(+)$-melezitose hydrate, $\mathrm{D}(+)$-sucrose, and $\mathrm{D}(+)$-trehalose). All other chemicals and solvents were of analytical grade purity and purchased from common suppliers. Water was treated in a Milli-Q water purification system (TGI Pure Water Systems, Greenville, SC, USA).

\subsection{Plant Material}

Cytinus hypocistis (L.) L. subsp. macranthus Wettst plants were collected in July 2018 from the host species Halimium lasianthum subsp. alyssoides (Lam.) Greuter at three different locations in Castro Daire, Portugal. Plant identification and characterization were conducted using Flora Europaea [14] botanical criteria and the online platform flora.on coordinated by the Portuguese Botanical Association. The fresh material was thoroughly cleaned with deionized water to remove all soil, drained on absorbent tissue, and frozen at $-30^{\circ} \mathrm{C}$. After lyophilization (FreeZone 4.5 model 7750031, Labconco, KS, USA), as shown in Figure 2, dried plants were separated into two different samples, whole plant $(\mathrm{CH})$ and nectar $(\mathrm{NCH})$, and reduced to a fine dried powder (20 mesh). The dried powders were stored at $-30{ }^{\circ} \mathrm{C}$ and protected from light until further analysis. 


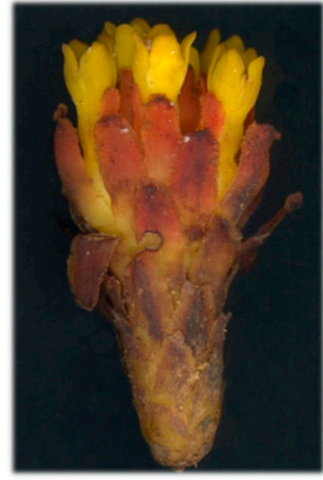

(a)

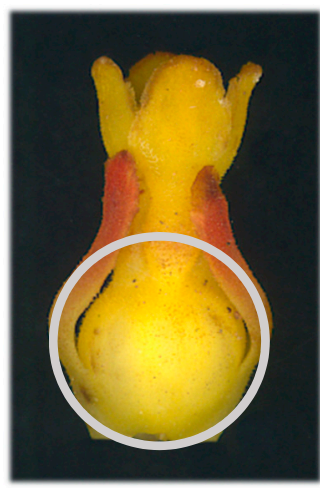

(c)

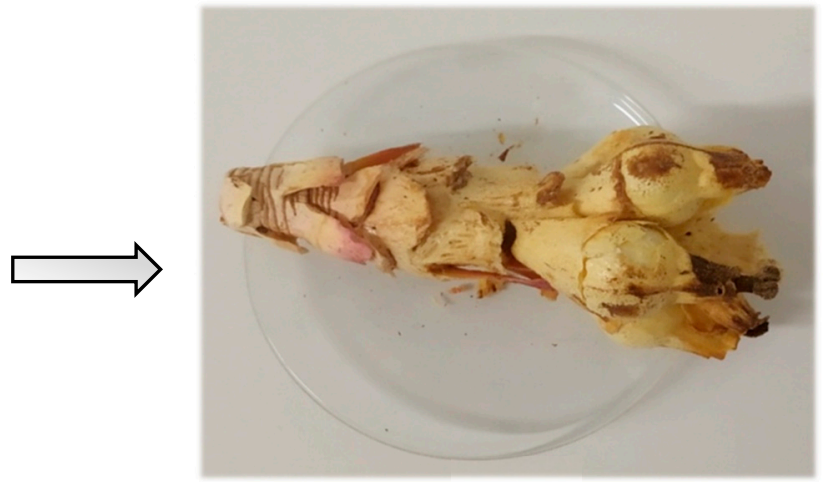

(b)

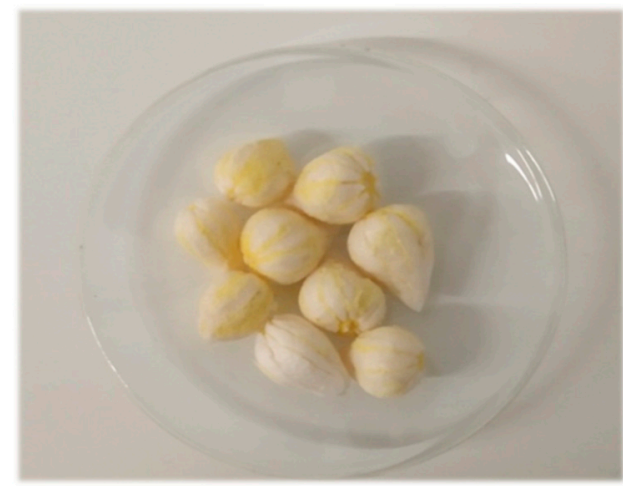

(d)

Figure 2. Cytinus hypocistis subsp. macranthus Wettst. (L.) L.: (a) fresh plant, (b) lyophilized plant, (c) fresh flower, and (d) lyophilized nectar.

\subsection{Nutritional Value of Cytinus hypocistis (L.) L. subsp. macranthus Wettst}

The proximate composition (i.e., proteins, fat, ash, fiber, and carbohydrates) and energetic value were evaluated in $\mathrm{CH}$ and $\mathrm{NCH}$. The crude protein content of the samples was determined following the macro-Kjeldahl method [ $\times$ 6.25, AOAC (Official Methods of Analysis of AOAC INTERNATIONAL) 991.02], the total fat using a Soxhlet apparatus with petroleum ether as the extraction solvent (AOAC 989.05), and the ash content by sample incineration at $550 \pm 15^{\circ} \mathrm{C}$ (AOAC 935.42) [37]. Fiber was determined based on the solubilization of non-cellulosic compounds using sulfuric acid and potassium hydroxide solutions (FIWE Fiber Analyzers). Total available carbohydrates were calculated by its difference, using the following equation: Total carbohydrates $(\mathrm{g} / 100 \mathrm{~g})=100-$ ( $g$ fat $+g$ protein $+g$ ash $+g$ fiber). Total energy was calculated according to the following equation: Energy $(\mathrm{kcal} / 100 \mathrm{~g})=4 \times(\mathrm{g}$ proteins $+\mathrm{g}$ carbohydrates $)+9 \times(\mathrm{g}$ fat $)+2 \times(\mathrm{g}$ fiber $)$.

\subsection{Chemical Characterization of Cytinus hypocistis (L.) L. subsp. macranthus Wettst}

\subsubsection{Soluble Sugars}

To determine the composition of the soluble sugars, $1 \mathrm{~g}$ of each sample $(\mathrm{CH}$ and $\mathrm{NCH})$ was mixed with melezitose (internal standard-IS, $25 \mathrm{mg} / \mathrm{mL}$ ) and extracted with $40 \mathrm{~mL}$ of $80 \%$ aqueous ethanol at $80{ }^{\circ} \mathrm{C}$, followed by solvent evaporation and fat removal with consecutive ethyl ether washes as previously described by Pereira et al. [38,39]. High-performance liquid chromatography (Knauer, Smartline system 1000, Berlin, Germany) coupled to a refractive index detector (HPLC-RI) was the chosen methodology and the data were analyzed using Clarity 2.4 Software (DataApex, Prague, Czech Republic). HPLC consisted of integrated equipment with a pump (Knauer, Smartline 
system 1000, Berlin, Germany), degasser (Smartline manager 5000), auto-sampler (AS-2057 Jasco, Easton, MD, USA), and an RI detector (Knauer Smartline 2300). Data were analyzed using Clarity 2.4 Software (DataApex). The chromatographic separation was achieved with a Eurospher 100-5 $\mathrm{NH}_{2}$ column $\left(4.6 \times 250 \mathrm{~mm}, 5 \mu \mathrm{m}\right.$, Knauer) operating at $30{ }^{\circ} \mathrm{C}$ (7971 R Graceoven). The mobile phase was acetonitrile/deionized water $(70: 30, v / v)$ at a flow rate of $1 \mathrm{~mL} / \mathrm{min}$. Identification was carried out by comparing authentic standard retention times, while quantification was achieved using the IS method (DataApex, Podohradska, Czech Republic), with calibration curves constructed from authentic standards. Soluble sugars were further expressed in g per $100 \mathrm{~g}$ of dry weight $(\mathrm{dw})$.

\subsubsection{Organic Acids}

Metaphosphoric acid (4.5\%) was added to $1 \mathrm{~g}$ of the sample; the mixture was then protected from light and incubated (with agitation) for $20 \mathrm{~min}$ at room temperature. After sample filtration, organic acids were determined using a Shimadzu 20A series UFLC (Shimadzu Corporation, Kyoto, Japan) coupled to photodiode array detector (PDA) [39]. Separation was achieved on a SphereClone (Phenomenex, Torrance, CA, USA) reverse phase $\mathrm{C}_{18}$ column $(5 \mu \mathrm{m}, 250 \mathrm{~mm} \times 4.6 \mathrm{~mm}$ i.d-internal diameter.) thermostatted at $35{ }^{\circ} \mathrm{C}$. The elution was performed with sulphuric acid ( $\left.3.6 \mathrm{mM}\right)$ using a flow rate of $0.8 \mathrm{~mL} / \mathrm{min}$. Detection was carried out in a PDA using 215 and $245 \mathrm{~nm}$ (for ascorbic acid) as preferred wavelengths. For the quantitative analysis, calibration curves with known concentrations of commercial standards were constructed, and the organic acids present in the two samples were determined by peak area comparison at $215 \mathrm{~nm}$ and $245 \mathrm{~nm}$ (for ascorbic acid). The results were expressed in $\mathrm{g}$ per $100 \mathrm{~g} \mathrm{dw}$.

\subsubsection{Fatty Acids}

Fatty acid content was investigated after trans-esterification of the lipid fraction obtained through Soxhlet extraction as previously described by Pinela et al. [38]. The samples were filtered with a $0.2 \mu \mathrm{m}$ nylon filter (Whatman) and analyzed by gas-liquid chromatography (DANI 1000, Contone, Switzerland) with flame ionization detection (GC-FID)/capillary column. The analysis was carried out with a split/splitless injector, an FID at $260{ }^{\circ} \mathrm{C}$, and a Zebron-Kame column $(30 \mathrm{~m} \times 0.25 \mathrm{~mm}$ i.d. $\times 0.20 \mu \mathrm{m}$ film thickness, Phenomenex, Torrance, CA, USA). The oven temperature program was as follows: The initial temperature of the column was $100{ }^{\circ} \mathrm{C}$, held for $2 \mathrm{~min}$, then a $10^{\circ} \mathrm{C} / \mathrm{min}$ ramp to $140{ }^{\circ} \mathrm{C}, 3{ }^{\circ} \mathrm{C} / \mathrm{min}$ ramp to $190{ }^{\circ} \mathrm{C}, 30{ }^{\circ} \mathrm{C} / \mathrm{min}$ ramp to $260{ }^{\circ} \mathrm{C}$, held for $2 \mathrm{~min}$. The carrier gas (hydrogen) flow rate was $1.1 \mathrm{~mL} / \mathrm{min}$, measured at $100^{\circ} \mathrm{C}$. Split injection (1:50) was carried out at $250{ }^{\circ} \mathrm{C}$. Fatty acid identification and quantification were achieved by comparing the relative retention times of the fatty acids methyl ester peaks with standards. The results were recorded and processed using CSW 1.7 software (DataApex 1.7) and expressed in the relative percentage for each fatty acid.

\subsubsection{Tocopherols}

Hexane solutions of butyl-hydroxy-toluene $(10 \mathrm{mg} / \mathrm{mL} ; 100 \mu \mathrm{L})$ and tocol (internal standard, $400 \mu \mathrm{L}$ at $50 \mu \mathrm{g} / \mathrm{mL}$ ) were added to $500 \mathrm{mg}$ of the sample prior to extraction, as formerly described by Pinela et al. [38]. The combination was then homogenized with $4 \mathrm{~mL}$ of methanol by vortex mixing (1 $\mathrm{min})$, followed by $4 \mathrm{~mL}$ of hexane (by vortex mixing for $1 \mathrm{~min}$ ). After sample homogenization, a saturated $\mathrm{NaCl}$ aqueous solution $(2 \mathrm{~mL}$ ) was added, the mixture was combined (vortex mixed for $1 \mathrm{~min}$ ), centrifuged ( $5 \mathrm{~min}, 4000 \mathrm{~g}$ ), and the clear upper layer carefully transferred to a vial. Sample extraction with hexane was performed three times. The combined extracts (i.e., the clear layer) were dried under a nitrogen stream, dissolved in $2 \mathrm{~mL}$ of $\mathrm{n}$-hexane, dehydrated with anhydrous sodium sulphate, filtered through a $0.2 \mu \mathrm{m}$ nylon filter (Whatman), transferred into a dark injection vial, and analyzed by HPLC (Knauer, Smartline system 1000, Berlin, Germany) coupled to a fluorescence detector (FP-2020; Jasco, Easton, MD, USA) [38]. The chromatographic separation was achieved with a Polyamide II (250 $\mathrm{mm} \times 4.6 \mathrm{~mm}$ i.d.) normal-phase column from YMC Waters operating at $30{ }^{\circ} \mathrm{C}$. The mobile phase used was a mixture of n-hexane and ethyl acetate $(70: 30, v / v)$ at a flow rate 
of $1 \mathrm{~mL} / \mathrm{min}$, and the injection volume was $20 \mu \mathrm{L}$. The fluorescence detector was programmed for excitation at $290 \mathrm{~nm}$ and emission at $330 \mathrm{~nm}$. The compounds were identified by chromatographic comparisons with authentic standards. Quantification was based on calibration curves obtained from commercial standards of each compound using the IS methodology. The results were expressed in $\mu \mathrm{g} / 100 \mathrm{~g} \mathrm{dw}$.

\subsection{Statistical Analysis}

$\mathrm{CH}$ and $\mathrm{NCH}$ samples were used for all the assays carried out in triplicate and the results were expressed as mean values and standard deviations (SD). The results were analyzed using a Student's $t$-test, in order to determine the significant difference between two different samples with a 5\% significance level (IBM SPSS Statistics, version 22.0. SPSS, Armonk, NY, USA).

\section{Conclusions}

Cytinus hypocistis subsp. macranthus Wettst. (L.) L. nectar has proven to be a good and balanced source of sugars and other carbohydrates, ash, proteins, lipids, and organic acids. This was a novel study of the nutritional and chemical characterization of this parasitic edible plant and allowed for a better understanding of the reasons behind the use of this plant in the past as a source of nutritional compounds during famine periods. Further investigation is needed to clarify potential applications of $C$. hypocistis. Therefore, a phytochemical characterization of the most bioactive molecules, such as phenolic compounds, could be determined and correlated to its biological properties in order to understand attributes given to this plant species.

Author Contributions: I.C.F.R. Ferreira and L.B. designed the experiments; A.R.S. performed all the experimental assays with the collaboration of A.F. in the nutritional analysis. A.R.S. and I.C.F.R. Ferreira wrote the manuscript; I.C.F.R. Ferreira, L.B., and P.A.G. revised the manuscript.

Acknowledgments: The authors are grateful to the Foundation for Science and Technology (FCT, Portugal) and FEDER under the Programme PT2020 for financial support to CIMO [UID/AGR/00690/2019], L. Barros contract, and A. Fernandes contracts. The authors would also like to thank Abílio Pereira de Carvalho for his extensive contribution to the specimens' harvest.

Conflicts of Interest: The authors state no conflict of interest.

\section{References}

1. Torija-Isasa, M.E.; Matallana-González, M.C. A Historical Perspective of Wild Plant Foods in the Mediterranean Area. In Mediterranean Wild Edible Plants; Springer: New York, NY, USA, 2016; pp. 3-13.

2. Łuczaj, Ł.; Pieroni, A.; Tardío, J.; Pardo-de-Santayana, M.; Sõukand, R.; Svanberg, I.; Kalle, R. Wild food plant use in 21st century Europe: The disappearance of old traditions and the search for new cuisines involving wild edibles. Acta Soc. Bot. Pol. 2012, 81, 359-370. [CrossRef]

3. Carvalho, A.M.; Barata, A.M. The Consumption of Wild Edible Plants. In Wild Plants, Mushrooms and Nuts; John Wiley \& Sons, Ltd.: Chichester, UK, 2016; pp. 159-198.

4. Jman Redzic, S. Wild Edible Plants and Their Traditional Use in the Human Nutrition in Bosnia-Herzegovina. Ecol. Food Nutr. 2006, 45, 189-232. [CrossRef]

5. Nebel, S.; Pieroni, A.; Heinrich, M. Ta chòrta: Wild edible greens used in the Graecanic area in Calabria, Southern Italy. Appetite 2006, 47, 333-342. [CrossRef] [PubMed]

6. Tarío, J.; Pardo-de-Santayana, M.; Morales, R. Ethnobotanical review of wild edible plants in Spain. Bot. J. Linn. Soc. 2006, 152, 27-71. [CrossRef]

7. Pardo-de-Santayana, M.; Tardío, J.; Blanco, E.; Carvalho, A.; Lastra, J.; San Miguel, E.; Morales, R. Traditional knowledge of wild edible plants used in the northwest of the Iberian Peninsula (Spain and Portugal): A comparative study. J. Ethnobiol. Ethnomed. 2007, 3, 27. [CrossRef] [PubMed]

8. Zucca, P.; Pintus, M.; Manzo, G.; Nieddu, M.; Steri, D.; Rinaldi, A.C. Antimicrobial, antioxidant and anti-tyrosinase properties of extracts of the Mediterranean parasitic plant Cytinus hypocistis. BMC Res. Notes 2015, 8, 562. [CrossRef] 
9. Quivik, F.L. The Illusory Boundary: Environment and Technology in History; Berghahn Books: New York, NY, USA, 2011; Volume 16, ISBN 9780813929880.

10. Rubiales, D.; Heide-Jørgensen, H.S. Parasitic Plants. Encycl. Life Sci. 2011. [CrossRef]

11. Těšitel, J. Functional biology of parasitic plants: A review. Plant Ecol. Evol. 2016, 149, 5-20. [CrossRef]

12. Westwood, J.H.; Yoder, J.I.; Timko, M.P.; dePamphilis, C.W. The evolution of parasitism in plants. Trends Plant Sci. 2010, 15, 227-235. [CrossRef] [PubMed]

13. De Vega, C.; Ortiz, P.L.; Arista, M.; Talavera, S. The endophytic system of mediterranean Cytinus (cytinaceae) developing on five host Cistaceae species. Ann. Bot. 2007, 100, 1209-1217. [CrossRef]

14. Tutin, T.G.; Burges, N.A.; Chater, A.O.; Edmondson, J.R.; Heywood, V.H.; Moore, D.M.; Valentine, D.H.; Walters, S.M.; Webb, D.A. (Eds.) Flora Europaea; Cambridge University Press: Cambridge, UK, 1993; ISBN 9780521410076.

15. Thorogood, C.J.; Hiscock, S.J. Host Specificity in the Parasitic Plant Cytinus hypocistis. Res. Lett. Ecol. 2007, 2007,84234 .

16. Carvalho, A.M.; Morales, R. Persistence of Wild Food and Wild Medicinal Plant Knowledge in a Northeastern Region of Portugal. In Ethnobotany in the New Era: People, Health and Wild Plant Resources; Pardo de Santayana, M., Pieroni, A., Puri, R., Eds.; Berghahn Books: Oxford, UK, 2010; pp. 147-171, ISBN 9781845458140.

17. Mlcek, J.; Rop, O. Fresh edible flowers of ornamental plants-A new source of nutraceutical foods. Trends Food Sci. Technol. 2011, 22, 561-569. [CrossRef]

18. Nicolson, S.W.; Nepi, M.; Pacini, E. Nectaries and Nectar; Springer: Berlin/Heidelberg, Germany, 2007; ISBN 9781402059377.

19. Schildknecht, H.; Herb, R.; Kunzelmann, P. Die Chemie der Schmarotzerblumen, II. Isoterchebin: Struktur des gelben Ellagitannin-Farbstoffes ausCytinus hypocistis (Rafflesiaceae). Liebigs Ann. der Chemie 1985, 1985, 1448-1456. [CrossRef]

20. Magiatis, P.; Pratsinis, H.; Kalpoutzakis, E.; Konstantinidou, A.; Davaris, P.; Skaltsounis, A.-L. Hydrolyzable Tannins, the Active Constituents of Three Greek Cytinus Taxa against Several Tumor Cell Lines. Biol. Pharm. Bull. 2001, 24, 707-709. [CrossRef] [PubMed]

21. Fernandes, L.; Casal, S.; Pereira, J.A.; Saraiva, J.A.; Ramalhosa, E. Edible flowers: A review of the nutritional, antioxidant, antimicrobial properties and effects on human health. J. Food Compos. Anal. 2017, 60, 38-50. [CrossRef]

22. Hanover, L.M.; White, J.S. Manufacturing, composition, and applications of fructose. Am. J. Clin Nutr. 1993, 58, 724S-732S. [CrossRef] [PubMed]

23. Zhou, Y.; He, W.; Zheng, W.; Tan, Q.; Xie, Z.; Zheng, C.; Hu, C. Fruit sugar and organic acid were significantly related to fruit $\mathrm{Mg}$ of six citrus cultivars. Food Chem. 2018, 259, 278-285. [CrossRef] [PubMed]

24. Lunn, J.; Theobald, H.E. The health effects of dietary unsaturated fatty acids. Nutr. Bull. 2006, 31, 178-224. [CrossRef]

25. Fernandes, L.; Ramalhosa, E.; Pereira, J.A.; Saraiva, J.A.; Casal, S. The Unexplored Potential of Edible Flowers Lipids. Agriculture 2018, 8, 146. [CrossRef]

26. Boden, G.; Sargrad, K.; Homko, C.; Mozzoli, M.; Stein, T.P. Effect of a Low-Carbohydrate Diet on Appetite, Blood Glucose Levels, and Insulin Resistance in Obese Patients with Type 2 Diabetes. Ann. Intern. Med. 2005, 142, 403. [CrossRef]

27. Peyron-Caso, E.; Taverna, M.; Guerre-Millo, M.; Véronèse, A.; Pacher, N.; Slama, G.; Rizkalla, S.W. Dietary (n-3) Polyunsaturated Fatty Acids Up-Regulate Plasma Leptin in Insulin-Resistant Rats. J. Nutr. 2002, 132, 2235-2240. [CrossRef] [PubMed]

28. Simopoulos, A.P. Essential fatty acids in health and chronic disease. Am. J. Clin. Nutr. 1999, 70, 560s-569s. [CrossRef] [PubMed]

29. Mozaffarian, D.; Geelen, A.; Brouwer, I.A.; Geleijnse, J.M.; Zock, P.L.; Katan, M.B. Effect of Fish Oil on Heart Rate in Humans. Circulation 2005, 112, 1945-1952. [CrossRef] [PubMed]

30. Tortosa-Caparrós, E.; Navas-Carrillo, D.; Marín, F.; Orenes-Piñero, E. Anti-inflammatory effects of omega 3 and omega 6 polyunsaturated fatty acids in cardiovascular disease and metabolic syndrome. Crit. Rev. Food Sci. Nutr. 2017, 57, 3421-3429. [CrossRef]

31. Ness, A. Diet, Nutrition and the Prevention of Chronic Diseases. WHO Technical Report Series 916. Report of a Joint WHO/FSA Expert Consultation. Int. J. Epidemiol. 2004, 33, 914-915. [CrossRef] 
32. Ricchi, M.; Odoardi, M.R.; Carulli, L.; Anzivino, C.; Ballestri, S.; Pinetti, A.; Fantoni, L.I.; Marra, F.; Bertolotti, M.; Banni, S.; et al. Differential effect of oleic and palmitic acid on lipid accumulation and apoptosis in cultured hepatocytes. J. Gastroenterol. Hepatol. 2009, 24, 830-840. [CrossRef] [PubMed]

33. Carvalho, I.S.; Teixeira, M.C.; Brodelius, M. Fatty acids profile of selected Artemisia spp. plants: Health promotion. LWT - Food Sci. Technol. 2011, 44, 293-298. [CrossRef]

34. French, M.A.; Sundram, K.; Clandinin, M.T. Cholesterolaemic effect of palmitic acid in relation to other dietary fatty acids. Asia Pac. J. Clin. Nutr. 2002, 11, S401-S407. [CrossRef]

35. Mancini, A.; Imperlini, E.; Nigro, E.; Montagnese, C.; Daniele, A.; Orrù, S.; Buono, P.; et al. Biological and Nutritional Properties of Palm Oil and Palmitic Acid: Effects on Health. Molecules 2015, 20, 17339-17361. [CrossRef]

36. Terés, S.; Barceló-Coblijn, G.; Benet, M.; Alvarez, R.; Bressani, R.; Halver, J.E.; Escribá, P.V. Oleic acid content is responsible for the reduction in blood pressure induced by olive oil. Proc. Natl. Acad. Sci. U S A 2008, 105, 13811-13816. [CrossRef]

37. Latimer, G.W., Jr. (Ed.) AOAC Official Methods of Analysis of AOAC INTERNATIONAL, 20th ed.; AOAC International: Rockville, MD, USA, 2016.

38. Pinela, J.; Barros, L.; Carvalho, A.M.; Ferreira, I.C.F.R. Influence of the drying method in the antioxidant potential and chemical composition of four shrubby flowering plants from the tribe Genisteae (Fabaceae). Food Chem. Toxicol. 2011, 49, 2983-2989. [CrossRef] [PubMed]

39. Pereira, E.; Barros, L.; Calhelha, R.C.; Dueñas, M.; Carvalho, A.M.; Santos-Buelga, C.; Ferreira, I.C. Bioactivity and phytochemical characterization of Arenaria montana L. Food Funct. 2014, 5, 1848-1855. [CrossRef] [PubMed]

Sample Availability: Samples of the plant species are available from the authors.

(C) 2019 by the authors. Licensee MDPI, Basel, Switzerland. This article is an open access article distributed under the terms and conditions of the Creative Commons Attribution (CC BY) license (http://creativecommons.org/licenses/by/4.0/). 